\title{
Timed up and go test and self-perceived health in elderly: population-based study
}

\section{Teste TUG e saúde autopercebida em idosos: estudo de base populacional}

\author{
Rosilene Andrade Silva Rodrigues ${ }^{1,2,3}$ \\ Margarete Marques Teodózio ${ }^{3}$ \\ Mariano Martínez Espinosa ${ }^{4}$ \\ Waléria Christiane Rezende Fett ${ }^{5}$ \\ Claudia Duarte $\mathrm{Melo}^{3}$ \\ Carlos Alexandre Fett' $1,2,5$
}

\begin{abstract}
Due to the aging process, chronic diseases arise with increased use of medications and there is a need to evaluate the elderly to prevent functional dependence and falls. The aim of this study was to compare gender, sociodemographic characteristics, fall occurrences, self-reported diseases, quantity of drugs with timed up and go test (TUG) and TUG-cognitive, and to associate these factors with the self-perception of health of the elderly in the community. Were selected 513 elderly people, with 384 that completed the TUG test to evaluate the functional capacity. There was difference between the female and male, in the variables: age-group 70 to 79 years $(\mathrm{p}=0.036) \geq 80$ years $(\mathrm{p}=0.013)$; per capita income in the female $\leq 1$ minimum wage $(p=0.005)$ and $>2(p=0.013)$, falls $(p=0.001)$, systemic hypertension $(\mathrm{p}<0.001)$, arthritis or rheumatism $(\mathrm{p}=0.033)$, depression $(\mathrm{p}=0.048)$, osteoporosis $(\mathrm{p}<0.001)$, medications 3 to $4(\mathrm{p}=0.008)$, self-perceived health $(\mathrm{p}=0.030)$ and in the TUG $(\mathrm{p}<0.001)$ and TUG-cognitive $(\mathrm{p}=0.002)$. The prevalence by Poisson regression Robust $\left(\mathrm{RP}_{\mathrm{a}}\right)$, the variables associated with health self-perceived: heart disease $(\mathrm{p}=0,047)$, stroke $(\mathrm{p}=<0,001)$, osteoporosis $(\mathrm{p}=0,013)$ and TUG motor $(\mathrm{p}=0,028)$. Women had more health problems, weakness and poor physical performance, indicating the need for special attention as the aging aspects. So, TUG test can be useful tool for risk evaluate of falls in the elderly living in the community.
\end{abstract}

Key words: Accidental falls; Aging; Chronic diseases; Frail elderly; Physical fitness.

Resumo - Devido ao processo envelhecimento, surgem as doenças crônicas com aumento de uso de medicamentos e existe necessidade de avaliar os idosos para prevenir dependência funcional e quedas. O objetivo deste estudo foi comparar as pessoas idosas por gênero, variáveis socioeconômicas, ocorrências de quedas, doenças autorrelatadas, quantidade de medicamentos, saúde autopercebida e teste Timed Up and Go (TUG). Foram selecionadas 513 pessoas idosas, com 384 que completaram o teste TUG para avaliar a capacidade funcional. Existia diferença entre gênero feminino e o masculino, nas variáveis: grupo etário de 70 a 79 anos $(p=0,036) \geq 80$ anos $(p=0,013)$; renda per capita no salário minimo $\leq 1$ feminino $(p=0,005)$ e $>2(p=0,013)$, quedas $(p=0,001)$, bipertensão sistêmica $(p<0,001)$, artrite ou reumatismo $(p=0,048)$, osteoporose $(p<0,001)$, medicamentos de 3 a $4(p=0,008)$, autopercepção de saúde $(p=0,030)$ e no TUG $(p<0,001)$ e TUG-cognitivo ( $p=0,002)$. A prevalência por regressão de Poisson robusta $(R P a)$, as variáveis associadas à saúde autopercebida: doença cardiaca $(p=0,047)$, acidente vascular cerebral ( $p=0,001)$, osteoporose $(p=0,013)$ e motor TUG $(p=0,028)$. As mulheres tiveram mais problemas de saúde, fraqueza e desempenho físico fraco, indicando a necessidade de atenção especial aos aspectos do envelhecimento. Assim, o teste TUG pode ser uma ferramenta útil para avaliar o risco de quedas nos idosos que vivem na comunidade.

Palavras-chave: Acidentes por quedas; Aptidão física; Doenças crônicas; Envelhecimento; Idoso frágil.
1 Universidade Federal de Mato Grosso. Programa de Pós-graduação da Faculdade de Ciências da Saúde da Faculdade de Medicina. Cuiabá, MT. Brasil.

2 Universidade Federal de Mato Grosso. Núcleo de aptidão física, informática, metabolismo esporte e saúde. Cuiabá, MT. Brasil.

3 Secretaria de Estado da Saúde de Mato Grosso. Cuiabá, MT. Brasil.

4 Universidade Federal de Mato Grosso. Departamento de Estatística do Instituto de Ciências Exatas e da Terra e Instituto de Saúde Coletiva. Cuiabá, MT. Brasil.

5 Universidade Federal de Mato Grosso. Programa de Pós-graduação da Faculdade Educação Física. Cuiabá, MT. Brasil.

Received: September 11, 2017 Accepted: April 17, 2018 


\section{INTRODUCTION}

With advancing age, the number of chronic diseases increases ${ }^{1}$ and consequently thus more use of medications in elderly population ${ }^{2}$. Thus, elderly people self-report illness a there is high percentage of poor and very poor health ${ }^{3}$. This population also presents functional losses that diminish or preclude the performance of daily activities ${ }^{3}$. Therefore is essential to evaluate the functional capacity of elderly ${ }^{4}$, people, aiming to improve the quality of life and prevent possible diseases and falls ${ }^{5}$.

The Timed Up and Go (TUG) test has been used for this evaluation ${ }^{6}$, it provides information on the functional capacity of the older adults. In addition to evaluating the mobility, the balance, transferring the position from sitting to standing, stability in walking, and gait speed or with higher risk of falls elderly people, as this involves posture, agility, and dynamic balance ${ }^{6,7}$. The TUG value up to 10 seconds is considered normal, from 10.01 to 20 seconds with compromised performance and over 20.01 seconds with higher risk of falls elderly ${ }^{7}$. In the study by Bohannon et $\mathrm{al}^{7}$, the TUG test measurement was stratified into three age groups as follows: 60-69 years with normative values of 8.1 (7.1-9.0) seconds, 70-79 years, with values of 9.2 (9.8-10.0) seconds, and 80-89 years with $11.3(10.2-12.7)$ seconds. The TUG cognitive ${ }^{8}$ that evaluates verbal fluency and verifies the cognitive capacity combined with the motor demand related to the performance of elderly people.

However, only the TUG test as a single tool should not be considered to evaluate the elderly at high risk of falls ${ }^{9}$ and it is necessary to know the health self-perception ${ }^{10}$ and the diseases self-reported by the elderly ${ }^{11}$. In addition, it is described a higher life expectancy for women ${ }^{12}$ and these will more often to the health service ${ }^{13}$. As for men, they have higher rates of physical performance capacity and less frequent the health service ${ }^{13}$. Moreover, it is not known how this health by of both genders, the functional capacity of mobility and balance and its impacts on self-perceived health of the elderly of this community. Still, this is the first population-based study with sample selection by probabilistic distribution and by draw of households maps provided by $\mathrm{IBGE}^{14}$. So, through information gathered will allows public policy subsidies for aging.

The chronic disease may correlate with functional disability in the elderly institutionalized ${ }^{15}$ or of the community ${ }^{4}$. However, it is not known that functional disability with samples in the general population of elderly living in this community associates poor reports of self-perceived health. In this way, knowing this health profile could propose preventive measures that delay the appearance of risk factors (e.g. falls) that lead to the reduction of the autonomy of the older adults. So, the study did a TUG test $t^{6,7}$ and not only self-report by questionnaires to know the state of functionality of the elderly ${ }^{3}$.

The aims of this study were to compare gender, sociodemographic characteristics, fall occurrences, self-reported diseases, quantity of drugs with timed up and go tests (TUG) and TUG-cognitive, and to associate these factors with the self-perception of health of the elderly in the community. 


\section{METHODOLOGICAL PROCEDURES}

\section{Study design and population}

This was a cross-sectional, population-based study carried out with elderly patients 65 years of age or over, of both sexes, living in the urban area. In maps provided by $\mathrm{IBGE}^{14}$, the court and streets whose homes were visited were identified, counted and drawn, with additional and proportional number selection of court. Thus, we identified 15 census tracts with density of elderly people representative of the population of Cuiabá city, counted and drawn the court and streets whose homes were visited by the interviewers.

The study was approved No. 632/09 (Resolution 466/12 of the National Health Council) by the Research Ethics Committee of the Júlio Muller University Hospital of the Federal University of Mato Grosso (UFMT). The sample size (n) was first determined through the method of simple random sampling.

\section{Inclusion and exclusion}

Were included all elderly people who had signed the Informed Consent Form and who achieved a score in the Mini Mental State Examination (MMSE) ${ }^{16}$ equal or above of 19 points. Were excluded: the wheelchairs or bedridden, presented serious stroke sequelae, had Parkinson's disease in advanced stages, were suffering any terminal illness, or who had cancer in general, except for skin cancer, who did not perform the TUG or TUG-cognitive.

\section{Dependent and independent variables}

In this study two dependent variables were considered: gender (male and female) and self-perception of health: (bad and very bad) and (very good/ good and regular). The independent variables were: age (in years); age group (in years) categorized in years in (60 to 69 years and 80 years or +); resides alone (not yes); schooling (illiterate, 1 to 4 years and 5 years or +); income ( $\leq 1 \mathrm{SM}, 1<\mathrm{x} \leq 2 \mathrm{SM}$ and did not respond); occurrence of falls (no, yes); cardiopathies (no, yes); systemic hypertension (SH) (not, yes); stroke (no, yes); diabetes mellitus (no, yes); tumor-cancer (not, yes); arthritis, rheumatism (no, yes); lung disease (no, yes); depression (no, yes); osteoporosis (not yes); quantity of drugs (5 or more, 3 to 4,1 to 2 and none); TUG and TUG-cognitive (in seconds) categorized ( $\leq 10$ seconds and $>10$ seconds).

\section{Data collection}

All the elderly was recruited from census tracts where of the households were drawn according to $\mathrm{IBGE}^{14}$ census tract maps. The first stage being the home visits to apply the interview forms related to the sociodemographic ${ }^{14}$, economic, reported diseases, and lifestyle characteristics, performed on all days of the week by trained interviewers. The second stage was performed on Saturdays with the physical tests. The interviews with a very broad formulary were carried out at the home of the elderly. The tests were performed on another day in order not to tire the elderly. It was still necessary 
to take the materials to the data collection site.

Was used to evaluate the economic conditions of the older adults based on monthly per capita income. To evaluate education, the number of complete years of study was considered and classified according to the criteria of the Brazilian Association of Research Companies (ABEP) as: illiterate, adult literacy, elementary, scientific, higher, postgraduate. Regarding comorbidities, the existence of self-reported illnesses ${ }^{10}$ in the previous year were inquired about, including: $\mathrm{SH}$, diabetes mellitus (DM), heart disease, stroke, tumor, cancer, arthritis, rheumatism, lung disease, depression, and osteoporosis.

\section{Physical evaluation}

The TUG test was used: a tape measure straight line for 3 meters marked on the ground, a chair approximately $46 \mathrm{~cm}$ in height, with arms at $65 \mathrm{~cm}$ in height and a stopwatch. The elderly was instructed to use normal footwear, walking cane or another accessory. In TUG motor, could not to talk in the test and TUG cognitive should to talk during the test the names of animals ${ }^{8}$, after the verbal command "go", and the time was measured in seconds ${ }^{7}$. The cut-off point for TUG-motor and TUG-cognitive was value up to 10 seconds is considered normal, from 10.01 to 20 seconds with compromised performance and over 20.01 seconds with higher risk of falls elderly ${ }^{7}$

\section{Statistical analysis}

The internal consistency of the data was tested with Cronbach's alpha coefficient and was found to be adequate $(\alpha>0.60)^{17}$. For the comparison of data of the continuous variables by gender the unpaired Student's t-test was used, and the $\mathrm{z}$-test for normal distribution and in the categorical variables the crude prevalence ratio $\left(\mathrm{RP}_{\mathrm{c}}\right)$ with its confidence interval $(95 \% \mathrm{CI})$ and the chi-squared test $\left(\mathrm{X}^{2}\right)$ of Pearson. Associations were made between the outcome (self-perception of health) and the independent variables. Then, the variables that showed association with values of $\mathrm{p}<0.20$ (chi-squared test) were selected to compose the multiple Poisson regression model $\left(\mathrm{RP}_{\mathrm{a}}\right)^{18}$. In the final model, only those with $\mathrm{p}$-value $<0.05$ remained. Note that in all associations the reference category was first in all variables considered.

\section{RESULTS}

Study participants were 384 elderly people aged 65 years or older, with 244 being female mean age was $72.41 \pm 6.30$ years and 140 elderly males with $72.06 \pm 5.34$ years. Shows that there were statistically significant differences, between the female and male groups of older adults in relation to the variables occurrences of falls $(p=0.001)$, systemic hypertension $(p<0.001)$, arthritis and rheumatism $(p=0.033)$, depression $(p=0.048)$, osteoporosis $(p<0.001)$, the amount of medication, in the 5 or more medications $(p=0.001)$ and 3 to 4 medications $(p=0.008)$ and categories, and self-perceived poor and very poor health $(p=0.030)$, (table 1$)$. 
Table 1. Comparison between gender by socioeconomic characteristics, occurrence of falls, selfreported diseases, quantity of drugs and self-perception health of the elderly in the community.

\begin{tabular}{|c|c|c|c|c|}
\hline \multirow[b]{2}{*}{ Variables } & \multirow[b]{2}{*}{ Category } & \multicolumn{2}{|c|}{ Gender } & \multirow[b]{2}{*}{$p$ value } \\
\hline & & $\begin{array}{c}\text { Female } \\
n=244(63.54)\end{array}$ & $\begin{array}{c}\text { Male } \\
n=140(36.46)\end{array}$ & \\
\hline Age & Mean \pm SD & $72.41 \pm 6.30$ & $72.06 \pm 5.34$ & $0.563^{*}$ \\
\hline \multirow{3}{*}{ Age group (in years) } & 60 to 69 years & $96(39.34)$ & $51(36.43)$ & $0.570^{*}$ \\
\hline & 70 to 79 years & $109(44.67)$ & 78 (55.71) & $0.036^{* *}$ \\
\hline & 80 years and + & 39 (15.98) & $11(7.86)$ & $0.013^{* *}$ \\
\hline \multirow{2}{*}{ Lives alone } & No & $204(83.61)$ & $120(85.71)$ & - \\
\hline & Yes & $40(16.39)$ & $20(14.29)$ & $0.578^{*}$ \\
\hline \multirow{3}{*}{ Education } & Illiterate & $58(23.77)$ & $33(23.57)$ & $0.965^{\star}$ \\
\hline & 1 to 4 years & $114(46.72)$ & $60(42.86)$ & $0.463^{*}$ \\
\hline & 5 years or + & $72(29.51)$ & $47(33.57)$ & $0.411^{*}$ \\
\hline \multirow{4}{*}{ Per capita income } & $\leq 1$ Minimum wage & $154(63.11)$ & $68(48.57)$ & $0.005^{* *}$ \\
\hline & $1<x \leq 2$ Minimum wage & $44(18.03)$ & $30(21.42)$ & $0.425^{\star}$ \\
\hline & $>2$ Minimum wage & $38(15.57)$ & $37(26.43)$ & $0.013^{* *}$ \\
\hline & Did not respond & $08(3.28)$ & $05(3.57)$ & $0.880^{\star}$ \\
\hline \multirow[t]{2}{*}{ Occurrences of falls } & No & $196(80.33)$ & $129(92.14)$ & - \\
\hline & Yes & $48(19.67)$ & $11(7.86)$ & 0.001 \\
\hline \multirow{2}{*}{ Heart disease } & No & $201(82.38)$ & $115(82.14)$ & - \\
\hline & Yes & $43(17.62)$ & $25(17.86)$ & 0.954 \\
\hline \multirow{2}{*}{ Systemic hypertension } & No & $58(23.77)$ & $59(42.14)$ & - \\
\hline & Yes & $186(76.23)$ & $81(57.86)$ & $<0.001$ \\
\hline \multirow{2}{*}{ Stroke } & No & $236(96.72)$ & $131(93.57)$ & - \\
\hline & Yes & $08(3.28)$ & $09(6.43)$ & 0.183 \\
\hline \multirow{2}{*}{ Diabetes mellitus } & No & $193(79.10)$ & $109(77.86)$ & - \\
\hline & Yes & $51(20.90)$ & $31(22.14)$ & 0.776 \\
\hline \multirow{2}{*}{ Tumor, cancer } & No & 237 (97.13) & $135(96.43)$ & - \\
\hline & Yes & $7(2.87)$ & $05(3.57)$ & 0.711 \\
\hline \multirow{2}{*}{ Arthritis, rheumatism } & No & $143(58.61)$ & 97 (69.29) & - \\
\hline & Yes & 101 (41.39) & $43(30.71)$ & 0.033 \\
\hline \multirow{2}{*}{ Lung disease } & No & $225(92.21)$ & $129(92.14)$ & - \\
\hline & Yes & $19(7.79)$ & $11(7.86)$ & 0.980 \\
\hline \multirow{2}{*}{ Depression } & No & $190(77.87)$ & $120(85.71)$ & - \\
\hline & Yes & $54(22.13)$ & 20 (14.29) & 0.048 \\
\hline \multirow{2}{*}{ Osteoporosis } & No & $133(54.51)$ & $126(90.00)$ & - \\
\hline & Yes & $111(45.49)$ & $14(10.00)$ & $<0.001$ \\
\hline \multirow{4}{*}{ Quantity of drugs } & 5 or more & $32(13.11)$ & $14(10.00)$ & 0.001 \\
\hline & 3 to 4 & 90 (36.89) & $34(24.29)$ & 0.008 \\
\hline & 1 to 2 & 99 (40.57) & $60(42.86)$ & 0.663 \\
\hline & None & $23(9.43)$ & $32(22.86)$ & 0.350 \\
\hline \multirow{4}{*}{ Self-perceived health } & Very good & $16(6.58)$ & $17(12.14)$ & 0.079 \\
\hline & Good & $86(35.24)$ & $58(41.43)$ & 0.231 \\
\hline & Regular & $118(48.36)$ & $59(42.14)$ & 0.237 \\
\hline & Poor or very poor & $24(9.84)$ & $06(4.29)$ & 0.030 \\
\hline
\end{tabular}

SD: Standard deviation. Numbers in parentheses to the right are the percentages. ${ }^{*} p$-values considering the unpaired t-test of Student's t distribution. ${ }^{* *}: p$-values considering the twoproportion z-test for normal distribution.

Table 2: the comparisons between the female and male groups of elderly people, for the TUG and TUG-cognitive variables, both being statistically significant $(p<0.001$ and $p=0.002)$. The TUG and the TUG-cognitive 
were also compared by gender, categorized in three categories showed statistically significant differences. In comparing the values of normal TUG versus with higher risk of falls performance of the elderly ${ }^{7}$, there was statistically significant differences $(p<0.001)$. The TUG-cognitive only presented statistical significance for the time 10 seconds or less category and for the more than 20 seconds category.

Table 2. Comparison between gender by timed up and go tests (TUG) and TUG-cognitive, of the elderly in the community.

\begin{tabular}{|c|c|c|c|c|}
\hline \multirow[b]{2}{*}{ Variables } & \multirow[b]{2}{*}{ Category } & \multicolumn{2}{|c|}{ Gender } & \multirow[b]{2}{*}{$p$-value } \\
\hline & & $\begin{array}{c}\text { Female } \\
n=244(63.54)\end{array}$ & $\begin{array}{c}\text { Male } \\
n=140(36.46)\end{array}$ & \\
\hline TUG motor & Mean \pm SD & $12.91 \pm 5.51$ & $10.53 \pm 3.91$ & $<0.001^{\star}$ \\
\hline TUG-cognitive & Mean \pm SD & $18.05 \pm 7.79$ & $15.58 \pm 6.99$ & $0.002^{*}$ \\
\hline \multirow{3}{*}{ TUG motor } & $\leq 10$ seconds & 65 (26.64) & 75 (53.57) & $<0.001^{* *}$ \\
\hline & 10,01 to 20 seconds & $161(65.98)$ & $62(44.29)$ & $<0.001^{\star *}$ \\
\hline & $>20$ seconds & $18(7.38)$ & $3(2.14)$ & $0.035 \mathrm{FE}$ \\
\hline \multirow{2}{*}{ TUG motor } & $\leq 10$ seconds & 65 (26.64) & 75 (53.57) & - \\
\hline & $>10$ seconds & $179(73.36)$ & $65(46.43)$ & $<0.001^{\star *}$ \\
\hline \multirow{3}{*}{ TUG-cognitive } & $\leq 10$ seconds & $20(8.20)$ & $24(17.14)$ & $0.014^{\star *}$ \\
\hline & 10,01 to 20 seconds. & $150(61.47)$ & $96(68.57)$ & $0.157^{\star *}$ \\
\hline & $>20$ seconds & $74(30.33)$ & $20(14.29)$ & $<0.001^{\star *}$ \\
\hline
\end{tabular}

TUG: Timed up and go test. SD: Standard deviation. Values in parentheses to the right are the percentages. ${ }^{*} p$-values considering the t-test of Student's t distribution. **: $p$-values considering the two-proportion z-test for normal distribution. FE: Fisher's exact test.

The female, has had 0.25 more prevalence ratio of times $(\mathrm{p}=0.026)$ in self-perceived health as poor or very poor. Elderly people with had heart disease $(0.29$ more times and $p=0.025)$, with hypertension $(0.24$ more times and $\mathrm{p}=0.044)$ in stroke $(0.81$ more times and $\mathrm{p}=0.001)$, rheumatoid arthritis ( 0.31 times more and $\mathrm{p}=0.005)$, with depression $(0.27$ more times and $\mathrm{p}=0.035)$, osteoporosis $(0.36$ more time and $\mathrm{p}=0.001)$, of prevalence ratio in self-perceived health as poor or very poor. As the number of users' medications 3-4 types ( 0.75 more times and $\mathrm{p}=0.001)$ of prevalence ratio in self-perceived health as poor or very poor. Elderly who made the TUG test $>10$ seconds ( 0.39 times more $\mathrm{p}=0.001)$ of prevalence ratio in self-perceived health as poor or very poor (table 3 ).

In the multiple regression model only stroke variables, heart disease, osteoporosis and TUG test showed statistical significance. Note that gender variable although not statistically significant in multiple model remained the same as an adjustment variable (table 4).

\section{DISCUSSION}

In the self-reported health, elderly women obtained $25 \%$ more complaints as bad or very poor when compared to elderly men. In self-reported diseases, this percentage reduced to $11 \%$ in elderly women. The main self-reported 
Table 3. Association between the self-perception of health (bad and very bad or very good/good and regular) and sociodemographic factors, occurrences of falls, self-reported diseases, quantity of drugs and time up and go (TUG) test, of the elderly in the community.

\begin{tabular}{|c|c|c|c|c|c|c|c|c|}
\hline \multirow{3}{*}{ Variables } & \multirow{3}{*}{ Category } & \multicolumn{4}{|c|}{ Self-perceived health } & \multirow{3}{*}{$\mathrm{PR}_{\mathrm{c}}$} & \multirow{3}{*}{ Cl 95\% } & \multirow{3}{*}{$p$-value } \\
\hline & & \multicolumn{2}{|c|}{ Bad and very bad } & \multicolumn{2}{|c|}{$\begin{array}{l}\text { very good/good and } \\
\text { regular }\end{array}$} & & & \\
\hline & & $n$ & $\%$ & $n$ & $\%$ & & & \\
\hline \multirow{2}{*}{ Gender } & Male & 65 & 46,43 & 75 & 53,57 & 1,00 & - & - \\
\hline & Female & 142 & 58,20 & 102 & 41,80 & 1,25 & {$[1,02 ; 1,54]$} & 0,026 \\
\hline \multirow{3}{*}{ Age group } & 60 to 69 years & 83 & 56,46 & 64 & 43,53 & 1,00 & - & - \\
\hline & 70 to 79 years & 99 & 52,94 & 88 & 47,06 & 0,94 & {$[0,77 ; 1,14]$} & 0,521 \\
\hline & 80 years or+ & 25 & 50,00 & 25 & 50,00 & 0,89 & {$[0,65 ; 1,21]$} & 0,428 \\
\hline \multirow{2}{*}{ Live alone } & No & 178 & 54,94 & 146 & 45,06 & 1,00 & - & - \\
\hline & Yes & 29 & 48,33 & 31 & 51,67 & 0,88 & {$[0,67 ; 1,16]$} & 0,346 \\
\hline \multirow{3}{*}{ Education } & 5 years or+ & 59 & 49,58 & 60 & 50,42 & 1,00 & - & - \\
\hline & 1 to 4 years & 95 & 54,60 & 79 & 45,40 & 1,10 & {$[0,88 ; 1,38]$} & 0,398 \\
\hline & Illiterate & 53 & 58,24 & 38 & 41,76 & 1,18 & {$[0,91 ; 1,51]$} & 0,212 \\
\hline \multirow{4}{*}{$\begin{array}{l}\text { Per capita } \\
\text { income }\end{array}$} & $>2 \mathrm{MW}$ & 35 & 46,67 & 40 & 53,33 & 1,00 & - & - \\
\hline & $1<\mathrm{x} \leq 2 \mathrm{MW}$ & 36 & 48,65 & 38 & 51,35 & 1,04 & {$[0,74 ; 1,46]$} & 0,809 \\
\hline & $\leq 1 \mathrm{MW}$ & 131 & 59,00 & 91 & 41,00 & 1,26 & {$[0,97 ; 1,85]$} & 0,063 \\
\hline & No answer & 5 & 38,46 & 8 & 61,54 & 0,82 & {$[0,40 ; 1,71]$} & 0,583 \\
\hline \multirow{2}{*}{$\begin{array}{l}\text { Occurrences } \\
\text { of falls }\end{array}$} & No & 174 & 53,54 & 151 & 46,46 & 1,00 & - & - \\
\hline & Yes & 33 & 55,93 & 26 & 44,07 & 1,04 & {$[0,82 ; 1,34]$} & 0,734 \\
\hline \multirow{2}{*}{ Heart disease } & No & 162 & 51,27 & 154 & 48,73 & 1,00 & - & - \\
\hline & Yes & 45 & 66,18 & 23 & 33,82 & 1,29 & {$[1,06 ; 1,58]$} & 0,025 \\
\hline \multirow{2}{*}{$\begin{array}{l}\text { Systemic } \\
\text { hypertension }\end{array}$} & No & 54 & 46,15 & 63 & 53,85 & 1,00 & - & - \\
\hline & Yes & 153 & 57,30 & 114 & 42,70 & 1,24 & {$[1,01 ; 1,55]$} & 0,044 \\
\hline \multirow{2}{*}{ Stroke } & No & 191 & 52,04 & 176 & 47,96 & 1,00 & - & - \\
\hline & Yes & 16 & 94,12 & 1 & 5,88 & 1,81 & {$[1,55 ; 2,11]$} & 0,001 \\
\hline \multirow{2}{*}{ Diabetes mellitus } & No & 161 & 53,31 & 141 & 46,69 & 1,00 & - & - \\
\hline & Yes & 46 & 56,10 & 36 & 43,90 & 1,05 & {$[0,85 ; 1,31]$} & 0,654 \\
\hline \multirow{2}{*}{ Tumor, câncer } & No & 199 & 53,49 & 173 & 46,51 & 1,00 & - & - \\
\hline & Yes & 8 & 66,67 & 4 & 33,33 & 1,25 & {$[0,83 ; 1,88]$} & 0,368 \\
\hline \multirow{2}{*}{$\begin{array}{l}\text { Arthritis, } \\
\text { rheumatism }\end{array}$} & No & 116 & 48,33 & 124 & 51,67 & 1,00 & - & - \\
\hline & Yes & 91 & 63,19 & 53 & 36,81 & 1,31 & {$[1,09 ; 1,59]$} & 0,005 \\
\hline \multirow{2}{*}{ Lung disease } & No & 188 & 53,11 & 166 & 46,89 & 1,00 & - & - \\
\hline & Yes & 19 & 63,33 & 11 & 36,67 & 1,19 & {$[0,89 ; 1,59]$} & 0,281 \\
\hline \multirow{2}{*}{ Depression } & No & 159 & 51,29 & 151 & 48,71 & 1,00 & - & - \\
\hline & Yes & 48 & 64,86 & 26 & 35,14 & 1,27 & {$[1,04 ; 1,54]$} & 0,035 \\
\hline \multirow{2}{*}{ Osteoporosis } & No & 125 & 48,26 & 134 & 51,74 & 1,00 & - & - \\
\hline & Yes & 82 & 65,60 & 43 & 34,40 & 1,36 & {$[1,14 ; 1,63]$} & 0,001 \\
\hline & None & 20 & 36,36 & 35 & 63,64 & 1,00 & - & - \\
\hline Quantity of & 1 to 2 & 80 & 50,31 & 79 & 49,69 & 1,38 & {$[0,94 ; 2,03]$} & 0,074 \\
\hline drugs & 3 to 4 & 79 & 63,71 & 45 & 36,29 & 1,75 & {$[1,20 ; 2,55]$} & 0,001 \\
\hline & 5 or more & 28 & 60,87 & 18 & 39,13 & 1,67 & {$[1,10 ; 2,55]$} & 0,014 \\
\hline THG motor & $\leq 10$ seconds & 60 & 43,17 & 79 & 56,83 & 1,00 & - & - \\
\hline - & $>10$ seconds & 147 & 60,00 & 98 & 40,00 & 1,39 & {$[1,12 ; 1,73]$} & 0,001 \\
\hline
\end{tabular}

Education: according to Brazilian Association of Research Companies-ABEP (2009). MW: Minimum wage. PRc: crude prevalence ratio in the Bivariate analysis. Cl: $95 \%$ confidence interval. p: significance level $(p<0.05)$ considering the of chi-square. 
Table 4. Prevalence ratio adjusted by robust Poisson regression ( $\mathrm{RPa})$, the variables associated with health self-perceived (bad and very bad) and (very good/good and regular), in the elderly in the community.

\begin{tabular}{llllc}
\hline Variables & Category & $\mathrm{PR}_{\mathrm{a}}$ & $95 \% \mathrm{Cl}$ & $\begin{array}{l}\mathrm{p} \text {-value } \\
\text { Valor } p\end{array}$ \\
Gender & Male & 1,00 & & \\
Heart disease & No & 1,11 & $0,88-1,39$ & 0,375 \\
& Yes & 1,00 & & \\
Stroke & No & 1,22 & $1,01-1,49$ & 0,047 \\
& Yes & 1,00 & & \\
Osteoporosis & No & 1,76 & $1,45-2,13$ & $<0,001$ \\
& Yes & 1,00 & & \\
\multirow{2}{*}{ TUG motor } & $\leq 10$ seconds & 1,28 & $1,05-1,55$ & 0,013 \\
\hline
\end{tabular}

PRa: prevalence ratio adjusted in the Poisson regression model with selection backward method. Significant at $5 \%$ level $(p<0.05)$. Cl-confidence interval in $95 \%$. The variable gender although not significant remained in the model as an adjustment variable.

diseases after multivariate analysis related to self-perception for both genders were found: cardiac disease, stroke, osteoporosis and TUG test over 10 seconds. More women were found, thus had feminization of old age, and with lower income living in the city different from the results of the State of Mato Grosso, higher survival of women, and belonging to classes $\mathrm{C}$ and $\mathrm{D}$.

Were found higher prevalence in females characterized greater feminization in this study living in the city and is considered to be generally due to a greater survival of women ${ }^{12}$, contradicting the state's Mato Grosso according with demographic data ${ }^{14}$. The women had lower per capita incomes with a higher percentage in classes $\mathrm{C}$ or $\mathrm{D}$. This result is in agreement with other studies with older adults in other states of Brazil2 ${ }^{20}$. It was observed that the older adults with low socioeconomic status were more vulnerable to the limitations of aging and that the women generally had lower income percapita ${ }^{21}$.

The occurrence of falls was higher in the female group compared to the male group, with a statistically significant difference. This result agrees with several studies showing a higher prevalence of falls in females ${ }^{5,22}$. According women suffer more falls due to being more fragile, because they have a maturity process which starts earlier than that of men ${ }^{23}$.

In this study, the comparison between the female and male groups of older adults indicated that the most prominent diseases were systemic hypertension ( $\mathrm{SH})$, arthritis and rheumatism, depression, and osteoporosis, with a prevalence of females in all the disease categories. Change in the cardiovascular system may lead to $\mathrm{SH}$, also having deleterious effects on the cognition, and the various disorders of senility gradually causing a reduction in the range of movements, affect balance and cause falls ${ }^{24}$. Osteoporosis is among the musculoskeletal disease ${ }^{25}$ and may be explained by endocrine changes in older women ${ }^{26}$.

The data obtained in the study showed differences in the amount 
of medications used by the male and female groups, with women being more prevalent in the 3 to 4 medications with significance statistical. The higher number of medications used by women is due to them reporting more chronic conditions ${ }^{2}$. This also confirms the findings of the present study in which the elderly women self-perceived a higher percentage of poor and very poor health $(9.84 \%)$ compared to the men, this difference being statistically significant.

In this study, the mean scores of the TUG and TUG-cognitive of the elderly female group were higher than those of the male group, with these differences being statistically significant. According to this difference is due to the fact that in the aging process sarcopenia may affect the musculoskeletal system and its functional capacity performance and interfere with hormonal, nutritional, metabolic and immunological factors ${ }^{23}$. There are differences in the physical composition of men and women throughout the life cycle, resulting in different physical performance due to body composition $^{20}$, thus justifying the lower female performance, corroborating with present study ${ }^{26}$. According to Bohannon et $\mathrm{al}^{7}$, older adults may have difficulty performing dual tasks with advancing age and this decline was associated with Parkinson's disease ${ }^{27}$.

Although the health status of the older adults in this study was selfreported, studies have shown that perceived morbidity coincides older people who reported having chronic diseases ${ }^{28}$ who considering the effect of ethnicity ${ }^{29}$ and racial difference in falls ${ }^{30}$. In this study, among all the variables analyzed in the anamnesis, five variables summarized the selfperception of health in the elderly. So, these questions should be explored due to lack of time for evaluation and the large number of elderly patients in clinics. It still suggests proposing public the exercises to improve the functionality, which prevents the early functional dependence in the elderly ${ }^{4}$. In cross-study there is a limitation to elucidate causality, therefore, new studies are needed to test these hypotheses.

\section{CONCLUSION}

This study concludes that self-related heart disease, stroke and osteoporosis associated with self-perception by the elderly, and the stroke showed higher risk for poor or very poor health of the elderly people. In the measurement of TUG test greater than 10 seconds was correlated with worse self-perceived health by the older adults. Thus, the TUG test can be useful tool for risk evaluate of falls in the elderly people. Thus, the study observed that the good health self-perception depends on the mobility and balance measured by the TUG and still on the health status reported by previous diseases in these elderly people. Therefore, it is proposed interventions and actions of health professionals in the promotion of health and prevention of falls the elderly women who self reported more diseases and obtained worse performance of mobility and functional capacity living in the community. 


\section{Acknowledgments}

The authors would like elderly people of the city.

\section{REFERENCES}

1. Dharmarajan K. Multimorbidity in Older Adults with Heart Failure. Clin Geriatr Med 2016;32(2):277-89.

2. Maher RL, Hanlon J, Hajjar ER. Clinical consequences of polypharmacy in elderly. Expert Opin Drug Saf 2014;13(1):57-65.

3. Castro DC, Nunes DP, Pagotto V, Pereira LV, Bachion MM, Nakatani AYK. Incapacidade funcional para atividades básicas de vida diária de idosos: estudo populacional. Ciênc Cuid Saúde 2016;15(1):109-117.

4. Mara D, Tavares S, Pelizaro PB, Sousa Pegorari M, Mapelli De Paiva M, Marchiori GF. Functional disability and associated factors in urban elderly: a population-based study. Rev Bras Cineant Desemp Hum 2016;18(5):499-508.

5. Cruz DT da, Ribeiro LC, Vieira M de T, Teixeira MTB, Bastos RR, Leite ICG. Prevalência de quedas e fatores associados em idosos. Rev Saude Publica 2012;46(1):138-46.

6. Mathias S, Nayak US, Isaacs B. Balance in elderly patients: the " get-up and go" test. Arch Phys Med Rehabil 1986;67(6):387-9.

7. Bohannon RW, Schaubert K. Long-term Reliability of the Timed Up-and-Go Test among Community-Dwelling Elders. J Phys Ther Sci 2005;17(2):93-6.

8. Virtuoso JF, Perdona Gregório LP, De Medeiros PA, Mazo GZ. O “Timed Up and Go" na previsão e explicação de quedas em idosos praticantes de exercícios físicos. Rev Bras Cineantropom Desempenho Hum 2014;16(4):381-9.

9. Barry E, Galvin R, Keogh C, Horgan F, Fahey T, Tinetti M, et al. Is the Timed Up and Go test a useful predictor of risk of falls in community dwelling older adults: a systematic review and meta- analysis. BMC Geriatr 2014;14(1):1-14.

10. Chen $Y$, While AE, Hicks A. Self-rated health and associated factors among older people living alone in Shanghai. Geriatr Gerontol Int 2015;15(4):457-64.

11. Zarini GG, Vaccaro JA, Canossa Terris MA, Exebio JC, Tokayer L, Antwi J, et al. Lifestyle Behaviors and Self-Rated Health: The Living for Health Program. J Environ Public Health 2014;2014:1-9.

12. Luy M GK. Do women live longer or do men die earlier? Reflections on the causes of sex differences in life expectancy. Gerontology,. 2014;60(2):143-53.

13. Fleith VD, Figueiredo MA, Figueiredo KF, Moura EC. Perfil de utilização de medicamentos em usuários da rede básica de saúde de Lorena, SP. Cien Saude Colet 2008;13:755-62.

14. Instituto Brasileiro de Geografia e Estatística - IBGE. IBGE-2010 [Internet]. 2010. Available from: http://www.ibge.gov.br/home/

15. Oliveira PH de, Mattos IE. Prevalência e fatores associados à incapacidade funcional em idosos institucionalizados no Município de Cuiabá, Estado de Mato Grosso, Brasil, 2009-2010. Epidemiol Serv Saúde 2012;21(3):395-406.

16. Brucki SMD, Nitrini R, Caramelli P, Bertolucci PHF, Okamoto IH. Sugestões para o uso do mini-exame do estado mental no Brasil. Arq Neuropsiquiatr 2003;61(3B):777-81.

17. Hair JF, Black WC, Babin BJ, Anderson RE, Tatham RL. Análise multivariada de dados. Bookman Editora; 2009. 126 p.

18. McGree JM, Eccleston JA. Robust Designs for Poisson Regression Models. Technometrics 2012;54(1):64-72.

19. Coutinho LMS, Scazufca M, Menezes PR. Métodos para estimar razão de prevalência em estudos de corte transversal. Rev Saude Publica 2008;42(6):992-8.

20. Falsarella GR, Gasparotto LPR, Barcelos CC, Coimbra IB, Moretto MC, Pascoa MA, et al. Body composition as a frailty marker for the elderly community. Clin Interv Aging 2015;10:1661-7. 
21. Pagotto V, Nakatani AYK, Silveira ÉA. Fatores associados à autoavaliação de saúde ruim em idosos usuários do Sistema Único de Saúde. Cad Saude Publica 2011;27(8):1593-602.

22. Ambrose AF, Paul G, Hausdorff JM. Risk factors for falls among older adults: a review of the literature. Maturitas 2013;75(1):51-61.

23. Clegg A, Young J, Iliffe S, Rikkert MO, Rockwood K. Frailty in elderly people. Lancet 2013;381(9868):752-62.

24. Freitas RS, Fernandes MH, Coqueiro R da S, Reis Júnior WM, Rocha SV, Brito TA. Capacidade funcional e fatores associados em idosos: estudo populacional. Acta Paul Enferm 2012;25(6):933-9.

25. Kim S, Won CW, Kim BS, Choi HR, Moon MY. The association between the low muscle mass and osteoporosis in elderly Korean people. J Korean Med Sci 2014;29(7):995-1000.

26. Guadalupe-Grau A, Carnicero J, Losa-Reyna J, Tresguerres J, Gimez-Cabrera M, Castillo C, et al. Endocrinology of Aging From a Muscle Function Point of View: Results From the Toledo Study for Healthy Aging. J Am Med Dir Assoc 2017;18(3):234-239.

27. Vance RC, Healy DG, Galvin R, French HP. Dual tasking with the timed “ up \& go" test improves detection of risk of falls in people with Parkinson disease. Phys Ther 2015;95(1):95-102.

28. Sibley KM, Voth J, Munce SE, Straus SE, Jaglal SB. Chronic disease and falls in community-dwelling Canadians over 65 years old: a population-based study exploring associations with number and pattern of chronic conditions. BMC Geriatr 2014;(1)14-22.

29. Su D, Wen M, Markides KS. Is Self-Rated Health Comparable Between NonHispanic Whites and Hispanics? Evidence From the Health and Retirement Study. J Gerontol B Psychol Sci Soc Sci 2013;68(4):622-32.

30. Han BH, Ferris R, Blaum C. Exploring Ethnic and Racial Differences in Falls Among Older Adults. J Community Health 2014; 39 (6):1241-1247

\section{CORRESPONDING AUTHOR}

Rosilene Andrade Silva Rodrigues Avenida França, 442. Bairro Santa Rosa

CEP 78.040.170 Cuiabá-MT

E-mail: rosilene.asr@gmail.com 